\title{
Kofi Awoonor in conversation with Hein Willemse
}

Kofi Awoonor was born on 13 March 1935 in the rural town of Wheta, Ghana. He completed degrees at the Universities of Ghana and London and gained his Ph.D. in Comparative Literature from the State University of New York at Stony Brook in 1972. Prior to furthering his studies in England he worked as a research fellow at the University of Ghana's Institute of African Studies, and later became the managing director of the Ghana Film Corporation. After the completion of his studies he became chairperson of the Comparative Literature Programme at Stony Brook. He also taught at the University of Texas at Austin, and returned to Ghana in 1975 to teach at the University of Cape Coast, Ghana's third university. Shortly after his return, he was imprisoned by the Acheampong military regime and released in 1976. From the early 1980s to the early 90s, he held a number of ambassadorial postings in Latin America and the United Nations. As Artist-in-Residence, he is still attached to the English Department, University of Ghana.

Awoonor is known primarily as a poet. He has published among others the following collections of poetry: Rediscovery and Other Poems (1964), Night of My Blood (1971), Ride Me, Memory (1973), The House by the Sea (1978), Until the Morning after (1987) and Latin American and Caribbean Notebook (1992). His best-known novel, This Earth, My Brother ... (1971), was followed in 1992 by Comes the Voyager at Last. His literary criticism appeared in The Breast of the Earth (1975), a book that is regarded a valuable survey of the relationship between oral literature and modern African literature. He also published several historical and political commentaries: The Ghana Revolution: A Background Account from a Personal Perspective (1984), Ghana: A Political History from Pre-European to Modern Times (1990) and Africa: The Marginalised Continent (1995).

What follows is an edited extract of a conversation between Awoonor and Hein Willemse that took place at the Don Suite Hotel, Rosebank, Johannesburg on $25^{\text {th }}$ February 2004. 
Why was there such a flourishing of Ghanaian writing in the sixties, early seventies? You were there, Efua Sutherland, Ayi Kwei Armah, Kwesi Brew, Ama Ata Aidoo, Atukwei Okai, and so forth - all prominent writers of Ghana.

That's a good question - that will enable us delve into the Nkrumah era, and its meaning for Ghana. Nkrumah was a phenomenal person because of the influence of his work in Ghana, particularly after he established the Republic in 1960. I was acting in the experimental theatre when I was at university in the late fifties. Efua Sutherland was the mother hen for the entire artistic development, particularly in the areas of theatre and children's literature. She established a drama studio. Within the drama studio we had a small group of writers that came together almost every Friday afternoon over beer and groundnuts. So there we were, the youngsters hanging around the older pioneer poets such as Kwesi Brew, Kayper Mensah, and others, lapping up the firmament of enthusiasm unleashed by Nkrumah.

Nkrumah was not only interested in the question of development, of physical structures or building a dam or a school. He had a blue print for artistic revival as an invaluable and intrinsic component of national development. He launched the Institute of African Studies, a School of Music and Drama, the Ghana Dance Ensemble, the Ghana Theatre Movement and the establishment of cultural centres in every single capital of all the regions of the country. Not only were museums developed; there were places for actors to stage plays. The Institute of African Studies supported a magazine called Okyeame, which played host to many writers. I remember James Baldwin visited. Julian Mayfield was there among us. Maya Angelou shared valuable time with us in the theatre. Richard Wright of course had been through. The whole of that African Diasporan inspiration of which Nkrumah was a major instigator, created for us opportunities to write.

The African rebirth which Nkrumah was launching around the concept of the African personality, i.e. the idea that the African is capable of handling his own affairs; the need for him to come out, take the stage and state his case and defend his position against all the denigrations that were being heaped upon him throughout the history of the past five hundred years of European intervention. Writing became the spontaneous outcome of this atmosphere. It was not only writing. It was also theatre, and the dance ensemble that was beginning to put together various dances of the country in a major choreographic construct that toured the country and went to Europe, the 
Soviet Union and ultimately the United States. The music scene was also part of it. Old instruments from the Asante court and the courts of other chiefs were modernised. These refashioned instruments became the nucleus of the Ghana National Orchestra, apart from the orchestra that plays European instruments. This is the orchestra that plays music purely with West African instruments that have been modernised. It is this entire range of activities that gave expression and fervour to Nkrumah's leadership.

Has that continued over the years?

It went on until the country hit a bad patch with the cycle of coups d'etat, beginning with the 1966 coup that toppled Nkrumah. Many of the writers left. Those who stayed didn't do much; their work sort of petered out. Efua Sutherland for instance was in the ambit of the cultural milieu that Nkrumah created. Once that milieu was shattered you had military bands and the military brass who were talking about how Nkrumah misruled the country, violations of human rights and so on. No art could flourish. Those of us who were writers and were part of the renaissance era didn't agree with that analysis, we didn't accept the CIA-inspired coup d'etat. There were consequences for many of us. I had to go into exile because I was targeted for persecution. So the original atmosphere having been destroyed, writing slowly grounded to a halt somehow. The younger people's writing - those who stayed behind - became very tentative. It wasn't as focussed, engaged and uplifting as the work of the independence generation. It was a trickle that didn't really mean much after the overthrow of Nkrumah. In the eighties it picked up again.

But don't forget, Ghanaians were writing way before us. A man called Hutton Brew, who came from an old mulatto family, is believed to be the author of the first novel, written in 1885 . He was the editor of one of the first indigenous newspapers in the Gold Coast. This novel, called Marita, was published anonymously by "a Native" and as a newspaper serial. Following that was J.E. Casely Hayford's Ethiopians Unbound (1911) and Kobena Sekyi's play, The Blinkards (1915). These writings reflected the discourse going on at the height of the colonial epoch that we need to be more familiar with. Our generation developed its energy from Nkrumah's vision. When that vision was removed there was a lot of national uncertainty and doubt. 
So, Nkrumah gave you, the younger writers, a sense of self-confidence? Yes indeed, very much so; not only the writers, but also the musicians, the artists, the carvers and the sculptors and so forth. A man like Saka Acquaye, a celebrated artist and musician, did some of the most fantastic sculptor pieces in the country and toured the Soviet Union with the first Ghanaian musical. He's about eighty now and the National Theatre just honoured him as a "Living Legend". After him the writers were honoured, me myself, Kwesi Brew, Ama Ata Aidoo and Ayi Kwei Armah.

Yet, if I read This Earth, My Brother ... correctly, you were at one point quite critical of Nkrumah, wasn't it?

Yes, very true. By 1965, I was an activist of the CPP [Convention People's Party] and part of a group that was very critical of the internal affairs of the Party and the way Nkrumah was running it. Nkrumah somehow encouraged a clique of old guards who were floundering in a sea of corruption and opulent living; then there was the issue of the misuse of the Preventive Detention Act (1958). It was first used against the violent opposition, the National Liberation Movement, based in the Asante heartland. Initially, Nkrumah used that Act effectively and if he hadn't done that, the problem that was going to emerge would have been the first post-colonial African civil war. But he also used it against members of his own Party who were dissenting against the direction of the Party. Some of us were very unhappy about this and we tried to articulate this in the folds of the Party. This Earth, My Brother... therefore, reflected some of the sense of unease and unhappiness at this development; but you've probably also noticed that I did not agree that he be blamed for everything. I was very cynical about a CIA-inspired coup led by the top military brass, who were thoroughly discredited. The book is very much an experimental novel; it's a poet's novel ...

That comment leads me to your craft of writing. One can see your conscious attention to the art of writing in This Earth, My Brother ..., and for example your poetry in Night of My Blood and so forth. That's somewhat different from that of many of your contemporaries - yours is a very conscious craft.

Yes, it is a very conscious craft. Whatever I'm saying now is post facto explanation. It was a very conscious exercise of craft in the sense that I thought that my writing should emanate from that deeper well of consciousness which was developing for me and looking at what it was that was confronting me in the society that I was living in. I'm also very 
interested in the mystical dimension of the artistic impulse, as you've noticed in the novel, hence my exploration of the myth of the feminine healer, woman of the ocean, as an intrinsic part of the act of atonement that was necessary for both the individual and the community.

What I also remember about that novel, which I've read ages ago, was the play on narrative structures - inside and then outside, stream of consciousness; the play on European intertexts, Dante and Kierkegaard and so forth. Apart from this interplay between the realism of the direct narrative and the poetic intercessions, I was also playing with the existentialist construct which had been made so powerfully available to us by writers like Camus and André Malraux. I'm aware not only of the intrinsic value of art, but also of art serving the function of social commentary ... putting together the multiplicity of, not only intellectual, but also social experiences. So there were comments that came out in Latin and pieces of prayers from the Roman Catholic Missal, which to me were part of the entire resource for literature, resource for art - weaving the protagonist through its interspaces; of course, underpinning it all is this mysticism I was playing with.

Do you agree with critics who call you an African syncretist, bringing together elements from your learning within an African traditional background? I agree with that entirely; whether the experiment works or not is a different matter. I have a theory that the artist is the one who goes in front of the people and therefore his experiences, sharpened, focused and multiple as they are, do locate him at the frontier of the totality of human experience. He is the one who sees more if he has the gift; if he's a real artist, he sees more than everybody else. Later on I realised that the artist and the diviner, the healer, the poet, the shaman or what you call here, the sangoma, are the same people. They represent a multiple set of artistic experiences that will have to attain some unification for it to mean something for the community. After all, he's not writing for himself; he's become a "spokesperson" - a very inadequate word. In Ghana we call him the okyeame, "linguist". So when you go to the chief's court the chief and all his people sit there and you're given a seat, the chief doesn't say a word. There's a fantastic orator at the court, the okyeame, and he's the one with the ritual gift of language. What is learned or experienced from the European exposure becomes a legitimate component of the total artistic resource from which I take ideas, sentiments, and sensations for incorporation into a unified artistic statement. 
Part of your syncretism relies quite heavily on the oral tradition. Are you conscious of the ritualistic, formulaic elements in your work? Your poetry in Rediscovery [and Other Poems] and in Night of My Blood, for instance, dealt with local dirges and rituals...

My very first serious attempts at writing began when I was an undergraduate. During this period, I was fascinated by the way myth and mythology were used in Western literature. One of my greatest models was Joyce's Ulysses. This represents for me an incredible return to an aboriginal source of literature, to Homer, who recounted the tales and myths out of which Joyce created a modernist reflection on the entire range of European experience. It's like saying, if you didn't go back, you can't move forward. The oral tradition for me became a resource, an amazing resource. In working for a Ph.D., I insisted on doing a thesis on the oral tradition as the feeding source of a good selection of African literature. I chose people like Achebe, Wole Soyinka and of course Amos Tutuola. My analyses of their texts and my own poetry revealed that there were forms embedded in the original oral material which can serve the purpose of modern African literature very well. In my own work I began to retrieve some of these forms: the dirge, for instance. I have a long poem called "I heard a bird cry", which is a long elegy, a lamentation, a song of sorrow. My grandmother was a great performer in the dirge tradition and there was the ancient poet Akpalu. When I did my fieldwork in 1970, I met with him and he was the one who sang those incredible dirges. I even translated some of them and added my own bits and pieces. Like that famous one, "I'm on the world's extreme corner, / those who sit in the middle forget, / I can only go beyond and forget. / My people have been somewhere. / If I turn here the sun burns me, / If I turn there the rain beats me. / The firewood of this world is not for all to gather. / I can only go beyond and forget." I took this particular segment and I created a series of variations on it into what became "Songs of Sorrow".

You give it a very incantory structure...

Yes, and it was an authentic piece, an original resource which I thought I should be able to handle with some degree of competence. That's what Mazisi Kunene was doing for the recreation of those Chakan epics. It enriches our literature. It makes this old but new literature available for the rest of the world. 
During the eighties in South Africa we had a similar explosion of traditional Zulu poetry when the Cosatu poets, the trade union poets, began to use features from traditional Zulu poetry in their English poetry - to good effect.

Yes, that's interesting. Fantastic ... I must say I was inspired also by my association with some of my good friends in Asia. For some time, during my very, very progressive years, I was a member of the Afro-Asian Writers' Bureau, which was based in Colombo, Sri Lanka. I was going in and out of places like Indonesia, Algeria, China, and India. I discovered the poetry of Mao and Ho Chi Minh. I came across a lot of Indian poetry that was translated from the old classics and I said, "Oh, my goodness, we have stuff like that!" By that time, my writing career had begun. My belief in it was reinforced by what I found in Indian poetry, both in Hindi and what was done in Gujerati. I also found it, subsequently - even though he was such a maverick - in the work of Rabindranath Tagore, in what was normally considered Bengali poetry. My fascination with this became more expanded, and I had to go back and look more closely, and what I found was more exciting than what I'd been aware of. And it hasn't stopped. I began to design and construct theories of our literature from these possibilities. It was a foray into the very problematic of designing a theory of literature. I looked at those texts very carefully. Patterns of it exist in other literatures: the myth of the journey, the myth of the return, the circularity of human experience and the interlink between the human experience and the mystical, the spiritual that reinforces and validates the human experience. I have a feeling that this provides us a new direction, if our literature is not to end in the realist cul de sac that Western Literature is stuck in now. That's why people like Norman Mailer now wish to go to Egypt for their novels; this is legitimate as much as it provides another historical passage for the attainment of human solidarity.

Does that explain the similarities between what you're talking about and the work of South Americans like García Márquez?

Yes, thank you very much. Writers like García Márquez and Alejo Carpentier, the Cuban novelist, and others, represent the Latin American dimension of this construct. I got to Cuba about a year before Carpentier died. I don't know whether you know his famous book, The Lost Steps [Los pasos perdidos]? It's a fantastic novel about a journey into the Amazon by a Western researcher, a Spanish researcher, who confronts in this forest the ultra dimension of human experience by meet- 
ing a woman who was a combination of all the races. She was Indian, she was African, she was Chinese, she was European - Portuguese. And I said, "Ah, we've written this already! I know this story!" I'm glad you're mentioning the Latinos. Even the Latin realists, like Jorge Borges are of great relevance. I went back to his short stories and his other prose work. I saw that the Latin American landscape is so close to the African landscape. It's something Europe had once, but she abandoned it.

It probably has something to do with the influence of rationalism ... rationality, isn't it?

Exactly ... I mentioned how the Romantics of the eighteenth and nineteenth centuries sought to reconstruct the world beyond the Augustan period and they were each clobbered on the head and shut up. Poets like Tennyson carried on, even if not in very good verse. He reinvented and used the myth of Arthur, the Round Table and Camelot; it's an important element in the European mythic landscape which reinforced not only the nature of authority, but also the nature of power, the nature of loyalty and allegiance to a place and community, which the whole of the Arthurian myth was about, an echo of the Celtic allegiance that Yeats tried to revive, but was shunted aside. He was brought back into Irish nationalism: "Let's sing of our heroes, as against the heroes of England", legitimately as part of Irish nationalism.

\section{Is that the future of African Literature?}

I recently said to a young writer, “Don't be overwhelmed by ignorance: ignorance about your own society and your community. Go beyond the facade that's part of the modern set-up and look at your community. Search in the villages; look at all the things you've missed in your education." I tell my students in my Creative Writing class: "Before we begin, let's go back to your own towns, spend two or three days there; bring me a story - animal stories or spirit stories or ghost stories or stories of ancestral conduct and behaviour, a poem, a song." On their return, they're very excited about their discoveries. They had drifted away, their parents moved into the capital, and they forgot that they have hometowns, villages, and hamlets that are still in the rural country. From this, some of them begin to construct good poetry, good narratives. 
How would economic modernisation and the increasing dislocation of these young writers affect African Literature in the future? Considering that the broader movement is towards a global economic and political development away from the local.

Indeed, physical changes will and have affected our societies, but my belief is that the underlying spirituality that animates our communities remains a strong base from which our survival system was constructed. It is a system that took us through the Trans-Atlantic Slave Trade, and guaranteed our being here on both sides of the Atlantic. In the New World, even today, it is this spirituality that holds our people together and guarantees them a place on the planet, in spite of past and present horrors.

May I return to one aspect of your spirit world? I find the idea that any of the Ghanaian gods can be recalled or kicked out of the community absolutely fascinating because it fundamentally changes the relationship between deity and subject - it becomes a complex [reciprocal] relationship ... Indeed, we found Gods, and particularly in the Ewe country, when they failed us, or turn malevolent, they are driven out of the community. Tigare, a god from the north of Ghana, came south when I was a boy. He was driven away because he failed to fulfil his side of the bargain of support and defence for the people.

In Latin American and Caribbean Notebook, you've retained a very basic understanding of Pan-Africanism, namely that black people everywhere share a common experience - similar gods, spiritual expressions, slavery, oppression and colonialism.

I came to a deeper appreciation of the meaning of Africa when I met diasporan communities. I remember when I went to Suriname, during my diplomatic days, I visited a little village called Sandigon. As we approached the place, I noticed that they had made an arch of palm fronds across the only road leading to the town. The elders met us near the arch and poured libations; they offered a prayer. I took a look at them and I wondered, "Have I left home or what?" This is South America! They made a prayer to the Supreme God; one word kept coming up - they spoke a language that we Ghanaians could not understand but the word Onyankopon kept recurring. Onyankopon is an Akan word for the Supreme Deity. It means "one on whom when we lean we cannot fall". The elders then took us into a secret hut; there, they brought out the drums. The music was distinct. I said, "No, no, I 
know this music." We the Ghanaians looked at one another. A young girl did a little dance and I asked: "What is the name of this deity?" The deity was called Kromantin. Kromantin is a little coastal town between Accra and Cape Coast where the Dutch and later the British had a slave fort. During the Dutch and the British periods, the volume of the slave trade from Kromantin was very high. Those enslaved had gone to the New World, and there they created a deity called Kromantin, in remembrance of the place from where they left Africa. They said that Kromantin is a very powerful god; it can arrest you, it can capture you. You will climb a tree with your head down, up to the top of the branches, without knowing what you're doing. That is a manifestation of the god. For me, this reaffirms the mystery of place and the mystery of time, coming together in the combined consciousness of man, providing a survival mechanism that kept the slaves alive in this place they'd been dragged to in chains. The terrain was familiar but yet alien. So they had to people it with their own aboriginal, anthropological experiences from their memory. They're not doing it as a play; it's a ritual of self-affirmation and therefore of survival. That to me is the structural base for the Pan-Africanist ideology which must also assume religious or spiritual, anthropo-cultural reality. I saw it in Brazil. I saw it in the santeria houses in Cuba, in East Havana. Some of the priests are as white as snow; they're white people, who have been absorbed into this experience. I said: "It's only African spirituality which can do that!", embrace those beyond its original world, including even those whose ancestors enslaved us.

[Laughter] What did they say?

They were so excited. “Do you recognise it?" I said to them, "I'm coming from the place where it came from. I recognise it, it has picked up a few things here and there by force of necessity, but the belief you've invested it with is no different from the belief which our people have in it."

Let me go back to the survival construct. That to me defines the ultimate reality of the African experience. The slaves, after the plantations and the slave ships and the chains, could survive. I saw a bit of that, not in as strong a sense as in Latin America, in the syncretism that you find in the black churches of America, where the black Protestant manifestation was very much like an African religious experience: invocation, command and prayer, during which the devotees are in a state of perpetual agitation. 
At one point you, yourself, became part of the African Diasporan experience, isn't it - when you went in to exile.

In a sense, yes. I was also in quest of knowledge. I took a first degree at home; opportunity came to take up a scholarship that took me to London; later I got a job as a poet-in-residence at Stony Brook, New York. I met people like Alan Ginsberg, Jerome Rothenburg, Galway Kinnel, Denise Levertore, Louis Simpson, etc. I met the young Beat-generation poets. I was in touch with the black writers, George Macbeth, Amiri Baraka, Nikki Giovanni, and others. I began a dialogue with them; it was a dialogue of mutual recognition. They were my brothers and sisters, and that is something I carried across into my Latin American and Caribbean Notebook. I shared the experiences of my homeless brother on the corner of Haggle Park Road in the Rastafarian temples of Kingston. I began to witness to the activities of my brothers and sisters on the European continent, those who have been marooned in these places. The anguish that they manifest when they see you, "You are newly come from home? So how is home?" But somehow, they can't go home. Home is more than a place of memories, of emotions. Indeed it is the place where gods and humans meet on a daily basis.

Is that when you wrote Ride Me, Memory?

Ride Me, Memory is very much a tribute to that particular period, my entire American experience; the Latin American segment was to come later in Notebook.

Picking up on your comments around South America: somewhere you wrote a tribute to Pablo Neruda ["For Pablo Neruda" in The House by the Sea, 1978] which I found extremely interesting; simply because it's not something that happens frequently, at least not at that time, in African Literature.

I discovered South America first from a purely intellectual point of view. At that time I was reading a lot, and teaching, writing and working on a doctoral degree. I was interested in other voices, voices other than those I was familiar with. I got hold of Neruda and read him in translation. Later on I developed my capacity to read him in Spanish. I said to myself, "Let me get into this man, seek the meaning of such incredible phrases: his having 'soiled his hands in the dirt of the poor'". This wasn't only a Marxist, leftwing writer, but someone who has an intimate understanding of the conditions of poverty that have been induced in Latin America by the American imperium. Later, when I 
worked in Latin America, I could see what Pablo was talking about, those favelas, in the slums of Rio [de Janeiro], Caracas, and elsewhere. Because I was the only representative of my country in Latin America, with accreditation to eight countries, I travelled all over the place in pursuit of my calling, learning and absorbing what were new but familiar sensations.

\section{Were you accredited to Chile?}

I was not, because of the dictatorship at the time. We wouldn't touch Chile, but Pinochet appears in that poem under his middle name Ugarte ... So Latin America became my second consciousness, beyond the American consciousness. I had to grasp its meaning vis-à-vis the America I had experienced for eight years. To me, it was the other America no less authentic and real as the imperium. I arrived in America just before Nixon came to power; the Vietnam War had been escalated, the antiwar movement was on. The Black Power Movement was raging. I was involved in drafting, in creating the Black Studies Programme at the State University of New York - Stony Brook. My contribution dealt with African history, African Literature; to be linked with the artistic expressions and the experiences of black people in America, going back to DuBois, Laurence Dunbar, Phillis Wheatley, Langston Hughes, the Harlem Renaissance and the articulate voices of the Black Aesthetic. I'm a lucky person; not many of us are given these opportunities. I suspect my work has been enriched by all of these experiences.

Oh, our time is running out. My last question: is there any new writing in the offing?

Yes, there's a collection of essays spanning 35 years that I've just finished putting together. It's a kind of testamental documentation of the issues that have shaped my life and raged in my soul. I think it's a useful exercise to do at this point of one's career, make a direct statement as I approach the $70^{\text {th }}$ year of my life. I've also put together a new collection of poetry, called Herding the Lost Lamb. It was poorly handled by a local publisher. So I could not use it. I am still roaming for a publisher. There's no money in poetry, they say. 